\title{
The influence of food intake on the development of structural and functional adaptation following ileal resection in the rat ${ }^{\mathrm{x}}$
}

\author{
H. MENGE ${ }^{2}$, M. GRÄFE, H. LORENZ-MEYER, AND E. O. RIECKEN \\ From the Medizinische Universitäts-Klinik, Marburg-an-der-Lahn, West Germany
}

SUMMARY The present study was undertaken to determine the influence of hyperphagia on the adaptive changes occurring in the rat jejunal mucosa as a result of intestinal resection. One group of resected rats was subjected to pair feeding with a sham-operated population, whilst another group was nourished ad libitum.

The animals which ate ad libitum developed hypertrophy of the mucosa which was accompanied by increased glucose absorption in vivo without changes in enzyme levels. These alterations were much less pronounced in the pair-fed group of resected animals, a finding that indicates that the adaptive changes are at least partially influenced by increased luminal nutrition.

Resection of a proximal or distal part of the small bowel provokes a marked hypertrophy of the mucosa of the remaining intestinal segment, which is accompanied by an increase in its absorptive capacity in vivo. Much attention has been directed to the role played by the increased intraluminal nutrition, accentuated by the onset of hyperphagia in such animals, in the development of this adaptation (Booth, Evans, Menzies, and Street, 1959; Dowling, 1974). In addition to much indirect evidence in favour of the hypothesis that luminal nutrition is essential for the maintenance of mucosal structure and function, we have recently provided a direct indication of the importance of the intestinal contents, when we demonstrated that the introduction of glucose into an excluded self-emptying blind loop partially reversed the atrophy provoked by the process of exclusion from continuity (Menge, Werner, Lorenz-Meyer, and Riecken, 1975). The present study was undertaken to explore under pair-fed and free-fed conditions the behaviour of the intestinal mucosa following resection so that the influence of food consumption, and hence of the luminal nutrition, on the adaptive changes in the mucosa could be directly investigated.

${ }^{1}$ Supported by the Deutsche Forschungsgemeinschaft Ri 136/8 u. 9

${ }^{2}$ Present address: Hôpital Cantonal Universitaire, Département de Chirurgie Expérimentale, Lausanne

Received for publication 3 April 1975.

\section{Methods}

Female Wistar rats weighing 170-190 g were employed. They were initially fed ad libitum with ground Altromin rat chow and tap water.

OPERATIVE TECHNIQUE

A resection of approximately $60 \%$ of the distal small intestine (IR) was performed under ether anaesthesia on 14 rats, and continuity of the gut was restored by end-to-end anastomosis. A further nine rats underwent a sham operation, whereby the intestine was cut and re-anastomosed without resection.

\section{POSTOPERATIVE PROCEDURES}

Following the operation, the rats were transferred to metabolic cages which permitted an exact evaluation of the daily food consumption. For the first three days after the operation, the animals were nourished simply with a sugared salt solution. Thereafter, nine of the ileal resected animals were provided only with the quantity of solid food that the paired controls had consumed on the preceding day. The food intake and the body weight of each animal of these two groups were measured daily. The remaining five ileal resected animals received their food ad libitum. On the 32nd postoperative day the intestines were examined.

LABORATORY INVESTIGATIONS

Determinations of glucose absorption in vivo and 
measurements of disaccharidase and dipeptidase activities in mucosal homogenates, as well as histological and morphometric examinations, were performed exactly as in the accompanying paper (Menge et al, 1975). In addition histochemistry of the mucosa was carried out as described previously (Menge, Bloch, Schaumlöffel, and Riecken, 1970). Quantitative evaluation was performed using a Leitz CMPV II microdensitometer: the results were corrected for the incubation time and the thickness of the samples, and were expressed as extinction $\cdot \min ^{-1} \cdot \mu^{-1}$.

\section{STATISTICAL EVALUATION}

Throughout, the results were analysed by means of the Wilcoxon test.

\section{Results}

\section{BODY WEIGHT}

The sham-operated control rats gained weight immediately after the operation, whereas the pairfed ileal resected animals maintained constant weight for six days. Thereafter, the weights rose in parallel (fig 1). Despite the fact that there was no
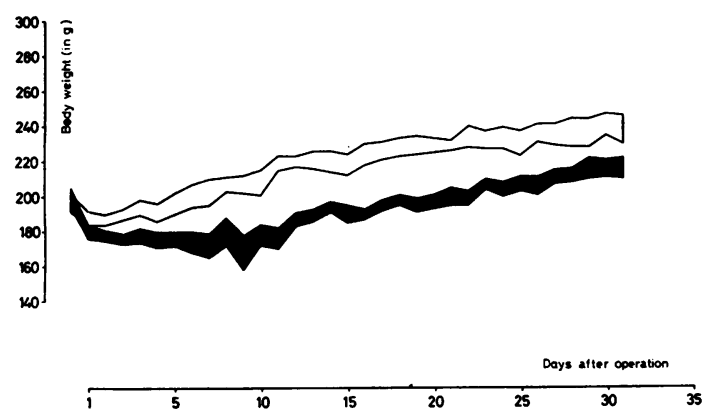

Fig 1 Body weight of sham-operated control rats and pair-fed resected animals. Space between two thin lines represents means $\pm S E M$ of controls, whilst shaded area represents means \pm SEM of operated animals.

difference in weights at the beginning of the experiment, the pair-fed ileal-resected rats had significantly lower body weights than the sham-operated controls at the end of the experiment. In contrast, the free-fed ileal-resected animals weighed the same as the controls (table I).

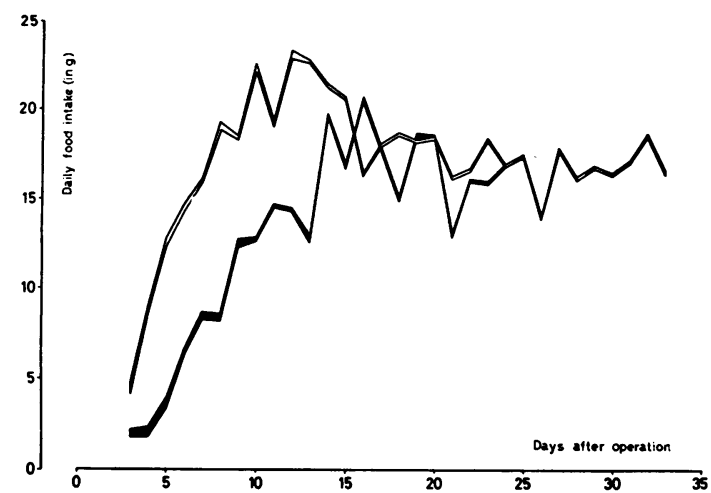

Fig 2 Daily food consumption of sham-operated rats and pair-fed resected animals. Explanation as in figure 1.

FOOD INTAKE

The amount of food consumed by the shamoperated rats rose constantly until the seventh postoperative day, then fell off for the next five days, at which stage it stabilized (fig 2). The IR animals consumed an increasing amount for the first seven days, but this quantity was always considerably less than that of the controls. For the next 15 days, the pair-fed ileal-resected rats ate approximately the same quantity as the shamoperated animals, though there often remained a small quantity of food in the cages. However, from the beginning of the fourth postoperative week, the animals obviously required more food than the controls, since the quantity offered was rapidly devoured and no traces remained.

\section{HISTOLOGY AND MORPHOMETRY}

There was no apparent difference in the mucosal structure of the control and pair-fed ileal-resected animals. The free-fed ileal-resected rats possessed evidently hypertrophic mucosae. Comparison of the morphometric parameters of the pair-fed ileal-resected animals with the controls revealed a tendency towards increased villus height, crypt length, villus width and epithelial cell height, but in no case did the difference reach the $5 \%$ probability threshold

\begin{tabular}{llllll}
\hline $\begin{array}{l}\text { Sham-operated Rats } \\
(n=9)\end{array}$ & \multicolumn{2}{l}{ Rats with Ileal Resection } & & \multicolumn{2}{l}{ Comparison (Wilcoxon Test) } \\
\cline { 2 - 3 } & Pair-fed $(n=9)$ & Free-fed $(n=9)$ & & Pair-fed:Controls & Free-fed:Pair-fed \\
\hline $236 \pm 6.4$ & $216 \pm 4.5$ & $234 \pm 11.5$ & & $2 \alpha<0.01$ & $2 \alpha>0.05$ \\
\hline
\end{tabular}

Table I Body weight in grams at end of experiment ${ }^{1}$

${ }^{1}$ Results (in this and subsequent tables) expressed as means \pm SEM of number of samples stated. 


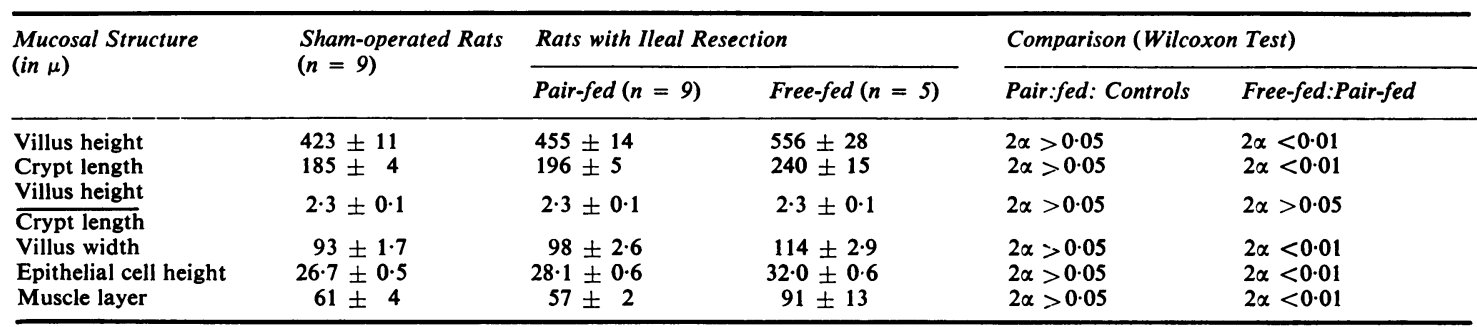

Table II Morphometric evaluation

\begin{tabular}{|c|c|c|c|c|}
\hline \multirow{2}{*}{$\begin{array}{l}\text { Sham-operated Animals } \\
(n=9)\end{array}$} & \multicolumn{2}{|c|}{ Rats with Ileal Resection } & \multicolumn{2}{|c|}{ Comparison (Wilcoxon Test) } \\
\hline & Pair-fed $(n=9)$ & Free-fed $(n=5)$ & Pair-fed:Controls & Free-fed:Pair-fed \\
\hline $1.60 \pm 0.07$ & $1.88 \pm 0.04$ & $2 \cdot 44 \pm 0.15$ & $2 \alpha<0.01$ & $2 \alpha<0.01$ \\
\hline
\end{tabular}

Table III Glucose absorption ${ }^{1}$

${ }^{1}$ Determined in vivo with a perfusion technique, expressed in $\mathrm{mg} \cdot \mathrm{cm}$ intestine $\mathrm{e}^{-1} \cdot \mathrm{h}^{-1}$.

\begin{tabular}{|c|c|c|c|c|c|}
\hline \multirow{2}{*}{$\begin{array}{l}\text { Enzyme Activity Studied } \\
\text { (U/g protein) }\end{array}$} & \multirow{2}{*}{$\begin{array}{l}\text { Sham-operated Rats } \\
(n=9)\end{array}$} & \multicolumn{2}{|c|}{ Rats with Ileal Resection } & \multicolumn{2}{|c|}{ Comparison (Wilcoxon Test) } \\
\hline & & Pair-fed $(n=9)$ & Free-fed $(n=5)$ & Pair-fed:Controls & Free-fed:Pair-fed \\
\hline $\begin{array}{l}\text { Lactase } \\
\text { L-methionyl-glycine- }\end{array}$ & $23 \cdot 7 \pm 3 \cdot 0$ & $19 \cdot 8 \pm 2 \cdot 7$ & $18 \cdot 7 \pm 1 \cdot 9$ & $2 \alpha>0.05$ & $2 \alpha>0.05$ \\
\hline $\begin{array}{l}\text { dipeptidase } \\
\text { Glycyl-L-leucine- }\end{array}$ & $445 \pm 34$ & $546 \pm 49$ & $587 \pm 46$ & $2 a>0.05$ & $2 \alpha>0.05$ \\
\hline $\begin{array}{l}\text { dipeptidase } \\
\text { L-phenylalanyl-L-proline- }\end{array}$ & $189 \pm 8$ & $193 \pm 8$ & $170 \pm 12$ & $2 \alpha>0.05$ & $2 \alpha>0.05$ \\
\hline dipeptidase & $374 \pm 24$ & $362 \pm 19$ & $321 \pm 17$ & $2 \alpha>0.06$ & $2 \alpha>0.05$ \\
\hline
\end{tabular}

Table IV Biochemical determinations of dipeptidase and dissacharidase activities

(table II). In contrast, the free-fed ileal-resected rats developed much taller and wider villi, deeper crypts, larger epithelial cells and thicker muscular layers.

\section{GLUCOSE ABSORPTION}

Glucose absorption was significantly increased in both groups of ileal-resected animals (table III), but the rise was much larger in the free-fed rats.

\section{BIOCHEMICAL FINDINGS}

The specific activities of maltase and lactase were the same in the three populations, when expressed in terms of the protein content of the homogenate (table IV). There was an increase in glycyl-L-leucine dipeptidase activity in both ileal-resected groups, but this was not accompanied by corresponding rises in the specific activities of the other dipeptidases examined (table IV).
QUANTITATIVE HIST OCHEMISTRY

Microdensitometric evaluation disclosed no significant differences in the activities of alkaline phosphatase, non-specific esterase or leucine aminopeptidase in the individual epithelial cells of the three populations (table V).

\section{Discussion}

In an attempt to explore the influence of nutritional factors on the adaptation of the remaining segment of intestine following resection, it was essential to remove a distal segment, since excision of the proximal bowel would automatically bring the distal intestine into contact with a richer diet. This was performed, however, in the knowledge that the adaptive changes in the proximal intestine following distal resection are much more modest than the alterations in distal segments subsequent to proximal resection (Booth et al, 1959). 


\begin{tabular}{|c|c|c|c|c|c|}
\hline \multirow{2}{*}{$\begin{array}{l}\text { Enzyme Activity Studied } \\
\left(E \cdot \min ^{-1} \cdot \mu^{-1}\right) \cdot 10^{3}\end{array}$} & \multirow{2}{*}{$\begin{array}{l}\text { Sham-operated Rats } \\
(n=8)\end{array}$} & \multicolumn{2}{|c|}{ Rats with Ileal Resection } & \multicolumn{2}{|c|}{ Comparison (Wilcoxon Test) } \\
\hline & & Pair-fed $(n=8)$ & Free-fed $(n=5)$ & Pair-fed:Controls & Free fed:Pair-fed \\
\hline $\begin{array}{l}\text { Alkaline } \\
\text { phosphatase }\end{array}$ & $3.9 \pm 0.2$ & $4.6 \pm 0.3$ & $3.8 \pm 0.7$ & $2 \alpha>0.05$ & $2 \alpha>0.05$ \\
\hline $\begin{array}{l}\text { Non-specific esterase } \\
\text { Leucine aminopeptidase }\end{array}$ & $\begin{array}{r}10.9 \pm 0.7 \\
7.8 \pm 0.5\end{array}$ & $\begin{array}{r}11.6 \pm 0.7 \\
9.1 \pm 0.5\end{array}$ & $\begin{array}{l}10.7 \pm 0.8 \\
11.6 \pm 1.8\end{array}$ & $\begin{array}{l}2 \alpha>0.05 \\
2 \alpha>0.05\end{array}$ & $\begin{array}{l}2 \alpha>0.05 \\
2 \alpha>0.05\end{array}$ \\
\hline
\end{tabular}

Table V Quantitative histochemistry of the intestinal epithelium

The mucosal hypertrophy in the free-fed IR rats corresponds to that described by other investigators (Booth et al, 1959; Dowling and Booth, 1967). The ratio, villus height:crypt length, was unchanged, indicating that no zonal transformation of the mucosa occurred (Riecken and Menge, 1974). The enzymological results also agree with the findings of Gleeson, Dowling, and Peters (1972), who reported that there was no change in the specific activity of a variety of different mucosal enzymes, though there was an increase in their levels when expressed per unit length of intestine. Our histochemical results, which represent a factor not previously investigated in the context of intestinal resection, confirm the absence of changes in enzyme activities at the cellular level. These results indicate that the stimulation of absorptive capacity, observed both in vivo (Bury, 1972; Dowling, 1974) and in vitro (Robinson, Haroud, Luisier, Winistörfer, and Mirkovitch, 1974), is in fact a consequence of the increase in the number of absorbing cells and therefore of the absorptive surface, rather than an augmentation in the activity of the individual cells. This would suggest that hyperplasia occurs, as shown by Gleeson et al (1972) with DNA measurements, alongside the hypertrophy of the individual cells which we have demonstrated morphometrically.

In comparison with the free-fed animals, the pair-fed rats developed very little mucosal hypertrophy: the glucose absorptive capacity was only slightly increased, and the changes in morphometric parameters, although showing a tendency towards hypertrophy, did not attain statistical significance. These findings strongly indicate that mucosal hypertrophy is caused largely by increased intraluminal nutrition. Indeed, hyperphagia appears to play an important role in the development of the hypertrophy which is established at a stage when the free-fed rats eat considerably more than the control animals. The fact that hyperphagia per se induces mucosal hypertrophy has been suggested by our studies on alloxan diabetes in rats, where a good correlation between villus height and food intake was observed (Lorenz-Meyer, Gottesbüren, Menge, Bloch, and Riecken, 1974), Furthermore, hyperphagia, as a result of intermittent starvation, has been reported to induce an enlargement of mucosal structure and an increase in absorptive capacity (Fábry, Kujalová, and Petrásek, 1959).

The slight changes occurring in the pair-fed group require comment: it is possible that they are initiated by intermittent starvation (Fábry et al, 1959), since these rats devoured their food immediately it was provided and were thus, by definition, starved for the rest of the day. On the other hand, further factors may be involved, as suggested by other investigators that hypertrophy can develop within two weeks of the resection (Dowling and Booth, 1967; Bury, 1972), that is to say, before the animals have started to increase their daily food consumption (fig 2). Thus if further factors are involved in the adaptive changes occurring after resection, no indication as to their nature can be gleaned from the present experiments.

We are grateful to Dr J. W. L. Robinson (Lausanne) for stimulating criticism and for help with the translation.

\section{References}

Booth, C. C., Evans, K. T., Menzies, T., and Street, D. F. (1959). Intestinal hypertrophy following partial resection of the small bowel in the rat. Brit. J. Surg., 46, 403-410.

Bury, K. D. (1972). Carbohydrate digestion and absorption after massive resection of the small intestine. Surg. Gynec. Obstet., $135,177-187$.

Dowling, R. H. (1974). The influence of luminal nutrition on intestinal adaptation after small bowel resection and by-pass. In Intestinal Adaptation: Proceedings of an International Conference on Anatomy, Physiology and Biochemistry of Intestinal Adaptation, edited by R. H. Dowling and E. O. Riecken, pp. 35-46. Schattauer, Stuttgart and New York.

Dowling, R. H., and Booth, C. C. (1967). Structural and functional changes following small intestinal resection in the rat. Clin. Sci., 32, 139-149.

Fábry, P., Kujalová, V., and Petrásek, R. (1959). Einige Folgeerscheinungen der funktionellen und morphologischen Adaptation an geänderte Kalorienzufuhr. Die Nahrung 3, 642-649.

Gleeson, M. H., Dowling, R. H., and Peters, T. J. (1972). Biochemical changes in intestinal mucosa after experimental small bowel by-pass in the rat. Clin. Sci. 43, 743-757.

Lorenz-Meyer, H., Gottesbüren, H., Menge, H., Bloch, R., and Riecken, E. O. (1974). Intestinal structure and function in relation to blood sugar levels and food intake in experimental diabetes. In Intestinal Adaptation: Proceedings of an International Conference on Anatomy, Physiology and Biochemistry of Intestinal Adaptation, edited by R. H. Dowling and E. O. Riecken, pp. 189-192. Schattauer, Stuttgart and New York.

Menge, H., Bloch R., Schaumlöffel, E., and Riecken, E. O. (1970). 
Transportstudien morphologische, morphometrische und histochemische Untersuchungen zum Verhalten der Dünndarmschleimhaut im operativ ausgeschalteten Jejunalabschnitt der Ratte. Z. ges. exp. Med., 153, 74-90.

Menge, H., Werner, H., Lorenz-Meyer, H., and Riecken, E. $O$. (1975). The nutritive effect of glucose on the structure and function of jejunal self-emptying blind loops in the rat. Gut 16, $462-467$.
Riecken, E. O., and Menge, H. (1974). Atrophic changes in rats. In Coeliac Disease: Proceedings of the Second Internatonal Coeliac Symposium, edited by W. Th. J. M. Hekkens and A. S. Peña, pp. 292-308. Stenfert Kroese, Leyden.

Robinson, J. W. L., Haroud, M., Luisier, A. L., Winistörfer, B., and Mirkovitch, V. (1974). Fonction et structure de la muqueuse intestinale après résection étendue de l'intestin grêle chez le chien. Biomedicine, 21, 71-76. 